\title{
New definition of environmental literacy and proposal for its international assessment in PISA 2015
}

\section{Petr Daniš}

Envigogika 8 (3) - Reviewed articles

Published 31. 12. 2013

DOI: http://dx.doi.org/10.14712/18023061.419

The article "A new definition of environmental literacy and a proposal for its international assessment in PISA 2015" by Petr Daniš has been published in the Czech issue of Envigogika 3/2013.

\begin{abstract}
This article presents a new definition of environmental literacy, published by the North American Association for Environmental Education (NAAEE) in December 2011. It briefly puts the new definition into the context of the evolution of environmental education on the international stage, introduces the new description of the domain of environmental literacy and its application in the framework for the assessment of environmental literacy in PISA 2015. The article initiates a discussion about its strengths and weaknesses and the further utility of this new definition in the context of the Czech Republic and abroad.
\end{abstract}

\section{Key words}

environmental education, environmental literacy, environmental literacy assessment, PISA

Nové vymezení environmentální gramotnosti a návrh na její mezinárodní testování v PISA 2015 (anglická verze)

\begin{abstract}
Abstrakt
Tento článek představuje nové vymezení environmentální gramotnosti, které zveřejnila Severoamerická asociace pro environmentální výchovu (NAAEE) v prosinci roku 2011. Stručně zasazuje nové vymezení do kontextu vývoje environmentální výchovy v mezinárodním prostředí, přibližuje nový popis oblasti environmentální gramotnosti a jeho aplikaci $\checkmark$ návrhu na hodnocení environmentální gramotnosti ve výzkumu PISA v roce 2015. Článek zahajuje diskusi o silných a slabých stránkách a další využitelnosti nového vymezení $\checkmark$ českém i zahraničním prostředí.
\end{abstract}

\section{Klíčová slova}

environmentální výchova; environmentální gramotnost; hodnocení environmentální gramotnosti; PISA 


\section{Introduction}

Environmental education continuously faces the need to clearly define the area in which it works, unambiguously articulate the goals that it pursues, and propose suitable methods for assessing the achievement of these goals.

This article presents a new definition of environmental literacy, published by the North American Association for Environmental Education (NAAEE) in December 2011 (Hollweg et al., 2011). This article has several objectives: to put the new definition into the context of the evolution of environmental education on the international stage, introduce the new description of the domain of environmental literacy established by the NAAEE, and demonstrate how the definition has been applied in the framework for the assessment of environmental literacy in PISA 2015. A further objective is to initiate a discussion about its strengths and weaknesses and the utility of this new definition in Czech and foreign contexts. It is not the purpose of the article to make any detailed analysis and comparison of other definitions of environmental education and environmental literacy or other attitudes to assessing environmental literacy.

\section{Clarification of terminology used}

This article uses the terms environmental education and environmental literacy. Quite intentionally, these terms are not defined at the beginning. One of the objectives of the article is to outline the evolution of the understanding of environmental education in the international context, and to demonstrate the NAAEE's new definition of environmental literacy against this backdrop. We will thus see that the understanding of environmental education is changing over time and that the development of environmental literacy has only been seen as the goal of environmental education in the last two decades. Environmental literacy itself will be defined and described in detail in Section 4, in which the new definition by the NAAEE is introduced.

The article uses the supportive terms domain and framework in connection with both environmental education and environmental literacy. The word domain suggests that environmental education and literacy are a certain field or area in which some things belong while others are outside it. Framework refers to a certain concept and constellation of what environmental education and environmental literacy comprises in various authors' views. Not only does it describe its components or variables, but it also tries to arrange them in a logical order and show the connections among them. While the terms domain and framework are common in professional English-language literature on environmental education (NAAEE, 2010a; Hollweg et al., 2011), they are not very common so far in connection with environmental education or literacy in the Czech literature. It is important to note that English literature does not treat these words as technical terms requiring precise definition but rather ordinary words that help us describe the terms environmental education and environmental literacy.

\section{Evolution of environmental education and (its) assessment in the international context}

It is not the ambition of this article to describe the evolution of environmental education, its assessment and assessment in general abroad in an exhaustive detail. Our purpose is to outline the evolution partially to provide the necessary context to enable the understanding 
of the NAAEE's new definition of environmental literacy. For this reason, we will focus mainly on three domains identified by the authors of the new definition as their primary sources of inspiration:

- pre-existing frameworks defining the domain of environmental education;

- recent nation-wide environmental literacy assessment in the USA and other countries;

- the Programme for International Student Assessment (PISA) implemented by the Organisation for Economic Co-operation and Development (OECD).

\subsection{Evolution of environmental education definitions}

The fundamental and widely accepted points of departure for defining the goals and strategies of environmental education are the Belgrade Charter and the Tbilisi Declaration. The Belgrade Charter (UNESCO, 1975) defined as the goal of environmental education "to develop a world population that is aware of, and concerned about, the environment and its associated problems, and which has the knowledge, skills, attitudes, motivations and commitment to work individually and collectively towards solutions to current problems, and the prevention of new ones". The Tbilisi Declaration (UNESCO, 1978) highlighted and described five categories of environmental education goals: awareness (of the environment and its problems), knowledge (understanding the environment and its problems), attitudes (values and motivations enabling involvement in improvement and protection of the environment), skills (recognise and solve environmental problems), and participation (being actively involved in solving environmental problems).

The subsequent definitions of environmental education followed from, and complemented, these points of departure. As the amount of research on and evaluation of various education programmes grew, it turned out that the initial point of departure did not contain all the variables that are important for environmental education (such as environmental sensitivity, self-efficacy, etc.). Therefore, a number of frameworks were established progressively in the Anglo-Saxon environment from the later 1970s, which suggested its division into various sub-domains in an effort to add the new findings describing the environmental education domain. Hungerford and Volk, for example published their influential model of responsible environmental behaviour (REB) in 1990, where they described knowledge, skills and other components connected with affectivity and behaviour and organised them at three levels: input variables, ownership variables and empowerment variables (Hungerford and Volk, 1990). Some frameworks defining environmental education were formulated in broader working groups (e.g., the 1994 work of the Environmental Education Literacy Consortium, composed of Hungerford, Volk, Wilke, Champeau, Marcinkowski, May, Bluhm and McKeown-Ice); others were for specific purposes such as introduction and dissemination of a new education programme (e.g., the WILD Project in 1986, the WET Project in 1993, etc.). In 1995, Bara Simmons's analysis quoted 20 different frameworks defining environmental education and searched for their basic common features and subdomains typical of most of them (an overview of the frameworks is also an annex to Exce/lence in Environmental Education: Guidelines for Learning (Pre K-12) - NAAEE, 2010a). This point of intersection then makes up the foundation for conceiving the discipline in standards (guidelines) for environmental education, published periodically by the NAAEE since 1999 as part of a project aiming to describe excellence in environmental education implementation (NAAEE, 2000, 2004, 2009, 2010a, 2010b, 2010c). 
The definition of the main environmental education goal itself has undergone an interesting evolution. Both the Belgrade Charter and the Tbilisi Declaration avoid short definitions and define the goal with an enumeration of goals defining the overall framework of environmental education (awareness, knowledge, skills, attitudes, motivations, etc.) (UNESCO 1975 and 1978). Hungerford and Volk (1990) defined the ultimate goal of environmental education as responsible environmental behaviour (action), a definition which became widespread in the Anglo-Saxon environment chiefly in the 1990s. More recent documents describe the ultimate goal of environmental education as development of environmental literacy or environmentally literate citizenry (NAAEE, 2009 a 2010a). We can only speculate about the chief reason for this shift: whether it is the broadening of the literacy concept in the entire education domain or a certain criticism of behaviourism, which comes down on any educational effort that declares its goal as a change of behaviour. However, it is advisable to realise that both the definitions essentially show two sides of the same coin: they emphasise either responsible environmental behaviour, to which the path is via developing knowledge, skills or competencies and other affective components (thus essentially developing environmental literacy), or development of environmental literacy as such, which enables making informed decisions concerning environmental quality and thus, ultimately, acting in an environmentally responsible fashion. The scope and the strategy remain similar in the concepts that use the two definitions; environmental education still focuses on developing analogous dispositions, knowledge, skills or competencies.

\subsection{Evolution of environmental literacy assessment}

Assessments of environmental education programmes have been elaborated since the 1970s. Various tools used for measuring the component variables in environmental education have also been developed since that time. For example, the New Environmental Paradigm - NEP (Dunlap and Van Liere, 1978) has been used as probably the most widespread tool for measuring pro-environmental attitudes. However, the effort to evaluate environmental literacy in its full breadth and at the level of entire populations only came about at the very end of the millennium. Tools for environmental literacy assessment were developed in the USA for students at ages roughly corresponding to the second tier of Czech primary school (Middle School Environmental Literacy Instrument - MSELI) and Czech secondary school (Secondary School Environmental Literacy Instrument - SSELI). The first nation-wide evaluations reflecting a broad understanding of environmental education appeared in Korea in 2005, Israel in 2008, and Turkey in 2009. Several phases of the National Environmental Literacy Assessment Project (NELA) took place progressively in the USA, starting in 2008. It involves selective assessment carried out on randomised samples of $6^{\text {th }}$ and $8^{\text {th }}$ grade pupils based on the MSELI tool, examination of the effect of established environmental education programmes on environmental literacy, etc. (description based on Hollweg et al., 2011). This new trend introduces increased requirements on a good definition of environmental literacy as a whole and distinction of its components, which can be verified in similar mass examinations. These requirements have led to the new definition of environmental education, which we will introduce in Section 4.

\subsection{PISA - International student literacy assessment}

Probably the most influential tool for evaluation of pupils on an international scale began to be developed at the end of the last millennium. The OECD's Programme for International Student Assessment (PISA) is led by an effort to focus the assessment not on verification of results of school education but rather surveying knowledge and skills that pupils really need in life (OECD, 2013a). The programme launch was preceded by debates among education policy makers and academics within the OECD on whether schools today are capable of 
giving pupils competencies required for life in the $21^{\text {st }}$ century. A project focusing on definition and selection of such competencies necessary for asserting oneself in life and work (Defining and Selecting Competencies - DeSeCo) was conducted, involving many prominent personalities in various disciplines (OECD, 2005).

The PISA concentrates on the identification of the level of reading, mathematical and science literacy understood as the capacity for functional application of certain knowledge (contents) and skills (competencies) in a broad variety of situations (contexts). Testing has been carried out every three years since 2000 on a sample of fifteen-year-olds and has involved an increasing number of countries. The survey always focuses on all the three literacies (which is an opportunity for periodic comparison of data and monitoring of trends), but each year it focuses on one of them in more depth (providing sufficient amounts of information on the specific literacy), additionally offering another specific discipline as a complementary, optional part of the survey (OECD, 2013a).

The PISA research is governed by high quality standards and, according to some experts, "methodologically speaking, it represents the best of what is available in international knowledge and skills assessments". Quality is guaranteed by a number of measures: the survey focuses on diversity of the test assignments in terms of cultural contexts, the administration of the survey is carried out in accordance to strict rules and is inspected by independent quality inspectors, open tasks are evaluated by independent evaluators based on precise instructions and demanding training and their agreement is assessed, etc. (Straková, 2011).

The 2006 PISA survey focused on natural science literacy for the first time, including the following components (ÚIV, 2006):

- scientific knowledge and its application to recognition of topics, acquisition of new knowledge, explanation of natural phenomena, and deduction of well-founded conclusions on topics related to natural sciences;

- knowledge of the characteristic features of science as a form of human cognition and research;

- awareness of how science and technology contribute to our material, ideal and cultural environment;

- willingness to deal with ideas and topics related to science and think about them.

The overall framework for assessing science literacy in the survey contained several items, which overlapped into environmental education (such as knowledge of ecosystems and the biosphere, the environment as one of the five contexts for the test tasks, attitudes to natural resources and the environment). The survey generated the first internationally comparable data on what students know about the environment and the related problems, from where they get this knowledge, what their attitudes are to environmental issues, and how their results in the environmental science are related to their environmental attitudes. The book Green at Fifteen (OECD, 2009) presented a summary of the main findings from the analysis of these data. These trends have probably led to the proposal to integrate environmental literacy as a complementary, optional component of the PISA 2015 survey, where natural science literacy will again be the main area of study. 


\section{The NAAEE project: a new definition of environmental literacy and a framework for its assessment}

The objective of the project implemented under the NAAEE was to establish a new, easy to understand description of environmental literacy founded on research findings, and to apply it to create a framework for assessing environmental literacy. The project involved experts on assessment and evaluation in the areas of environmental education, study of natural and social sciences and related scientific disciplines. The internal team was composed of Karen Hollweg (NAAEE), Jason Taylor (Nature Talks, LLC), Rodger Bybee (Biological Science Curriculum Study), Thomas Marcinkowski (Florida Institute of Technology), William McBeth (University of Wisconsin-Platteville), and Pablo Zoido (OECD/PISA); additional experts provided feedback, comments and suggestions for the first drafts.

The paper Developing a framework for assessing environmental literacy (Hollweg et al., 2011) is interesting not only for its results but also its procedure. The authors carefully weigh the existing findings in the area of environmental education. They openly ask questions and demonstrate the difficulties that they face, and justify the answers that they eventually favour. The paper makes use of the best past findings, makes a new description of the domain of environmental literacy as a current product, and makes it available and describes its potential future uses. Another important fact is that although the authors try their best to get a grip on the contemporary understanding of the discipline, their paper does not suggest their definition of environmental education and environmental literacy is inscribed in stone for all time, but provides a contemporary definition..

The following section will first make a more detailed introduction of both the new definition of environmental literacy and the description and arrangement of this domain. Furthermore, we will show a proposal for assessing environmental literacy in the 2015 PISA survey based on the new definition of environmental literacy.

\subsection{Definition of the domain of environmental literacy}

The new NAAEE framework defines an environmentally literate person "as someone who, both individually and together with others, makes informed decisions concerning the environment; is willing to act on these decisions to improve the well-being of other individuals, societies, and the global environment; and participates in civic life". Environmentally literate people have various measures of:

- knowledge and understanding concerning a wide range of environmental concepts, problems and issues,

- a set of cognitive and affective dispositions,

- $\quad$ a set of competencies (cognitive skills and abilities),

- appropriate behavioural strategies to apply such knowledge and understanding in order to make sound and effective decisions in a range of environmental contexts.

All these components (cognitive - knowledge, skills and abilities; affective and behavioural) are interconnected, affect each other, and may progressively develop in the course of every individual's life. This means that a person is not either environmentally literate or illiterate but rather evolves progressively in the environmental literacy continuum.

Diagram 1 is a more detailed representation of the components of environmental literacy and their interlinkages. In addition, Hollweg et al. (2011) make a detailed description 
of each of the items, explain the links and the reasons for including them in the overall framework, and document it all with lists of expert literature and research in which they ground their assertions.

Diagram 1: The domain of environmental literacy (Hollweg et al., 2011)

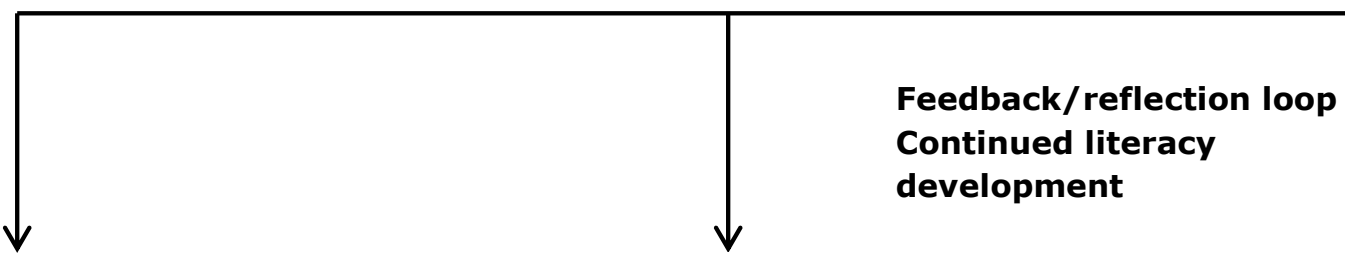

What you know about:

- Physical and ecological systems

- Social, cultural and political systems

- Environmental issues

- Multiple solutions to environmental issues

- Citizen participation and action strategies

\section{Dispositions}

How you respond to environmental issues:

- Sensitivity

- Attitudes and concern toward the environment

- Assumption of personal responsibility

- Locus of control/ Self-effi-

cacy

- Motivation, and intention to act
Skills and abilities that you know how and when to apply:

- Identify environmental issues

- Ask relevant questions about environmental conditions and issues

- Analyse environmental issues

- Investigate environmental issues (scientific and social aspects of issues using primary and secondary sources)

- Evaluate and make personal judgments about environmental issues (the interaction between environmental conditions and sociopolitical systems)

- Use evidence and knowledge to select and defend one's own position(s) to resolve issues

- Create and evaluate plans at various scales/levels to resolve environmental issues

\section{Environmental Responsible Behaviour}

Involvement in intentional and habitual behaviors, individually or as a member of a group, that work towards solving current problems and preventing new ones. 


\subsection{Proposal of a framework for assessing environmental literacy in PISA 2015}

Not every component and variable of environmental literacy can be assessed in questionnaire surveys or tests. What is more, PISA and similar surveys have to ensure the feasibility of the survey in a relatively short time, which also affects the quantity of components that can be assessed. The whole proposal is based on the assumption that assessment of environmental literacy will be included in the 2015 PISA survey as a complementary component to assessment of science literacy and that it will be allocated 60 minutes of the total test time. The above description of the environmental literacy domain therefore has to be simplified or narrowed down, while selecting its cardinal components so that the survey truly still assesses environmental literacy levels. The authors recommend a focus on four interconnected components of environmental literacy: contexts, competencies, environmental knowledge and dispositions towards the environment. Diagram 2 shows their basic structure.

Diagram 2: A proposed framework for assessing environmental literacy in PISA 2015 (Hollweg et al., 2011)

\section{Contexts}

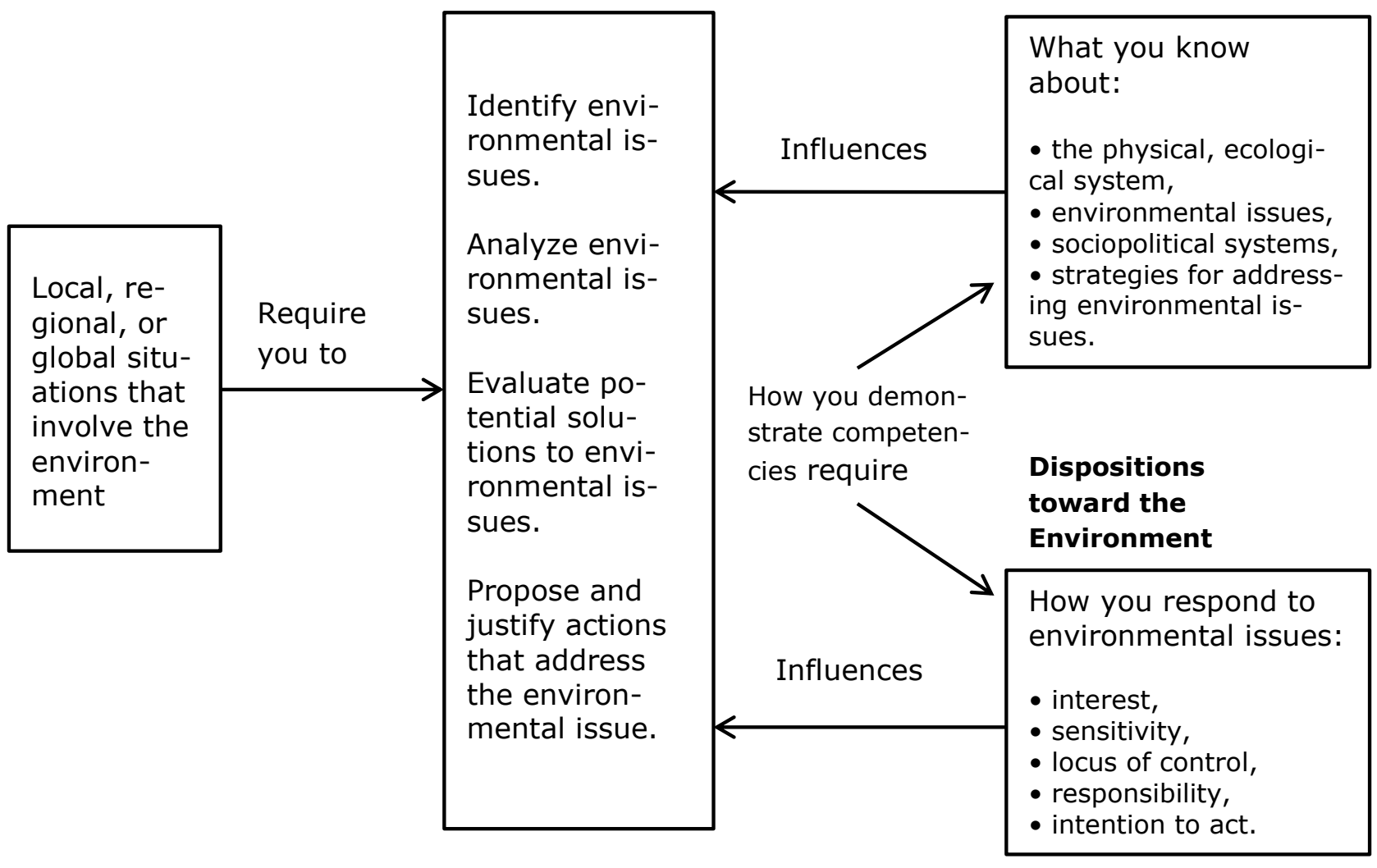

\section{Competencies}

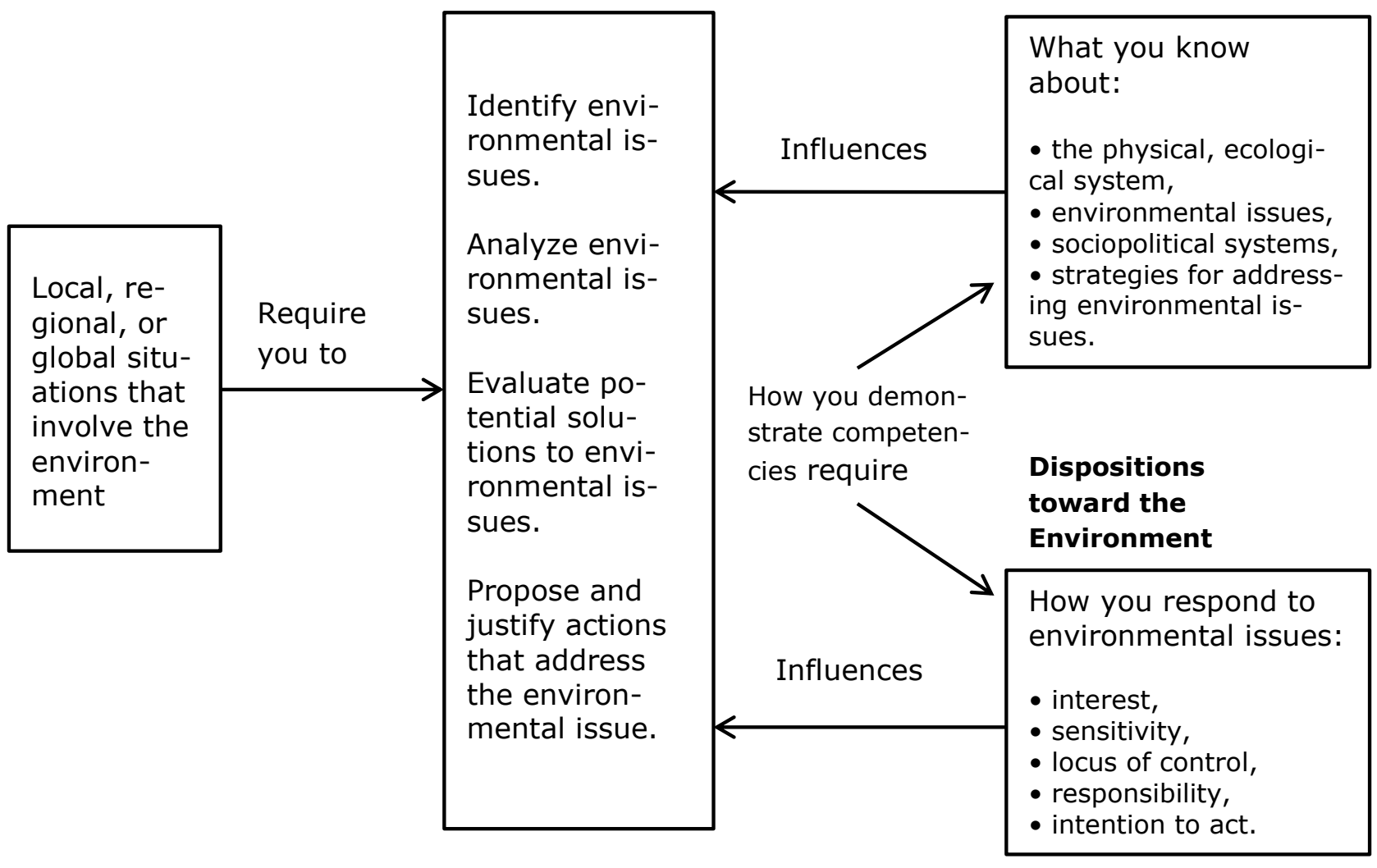

\section{Environmental} Knowledge

Hollweg et al. emphasise that environmental literacy assessment should encompass a sufficient breadth of various contexts in which it is manifested. The contexts should include situations from local to global, a range of topics from biodiversity to natural resources to 
land use, and should concern both personal and civic responsibilities. Their proposal of the contexts is shown in Table 1.

Table 1. Contexts for application of environmental literacy (Hollweg et al., 2011)

\begin{tabular}{|l|l|l|l|}
\hline & Local & Regional & Global \\
\hline Biodiversity & Flora and fauna & $\begin{array}{l}\text { Endangered spe- } \\
\text { cies, } \\
\text { habitat loss, exotic } \\
\text { invasive species }\end{array}$ & $\begin{array}{l}\text { Ecological sustaina- } \\
\text { bility, sustainable } \\
\text { use of species }\end{array}$ \\
\hline Population Growth & $\begin{array}{l}\text { Growth, birth/death, } \\
\text { emigration, immi- } \\
\text { gration }\end{array}$ & $\begin{array}{l}\text { Maintenance of hu- } \\
\text { man population, } \\
\text { population distribu- } \\
\text { tion, over popula- } \\
\text { tion }\end{array}$ & $\begin{array}{l}\text { Population growth } \\
\text { and its social, eco- } \\
\text { nomic, and environ- } \\
\text { mental conse- } \\
\text { quences }\end{array}$ \\
\hline Natural Resources & $\begin{array}{l}\text { Personal consump- } \\
\text { tion of materials }\end{array}$ & $\begin{array}{l}\text { Production and dis- } \\
\text { tributions of food, } \\
\text { water, energy }\end{array}$ & $\begin{array}{l}\text { Sustainable use of } \\
\text { renewable and non- } \\
\text { renewable resources }\end{array}$ \\
\hline $\begin{array}{l}\text { Environmental } \\
\text { Quality and Health }\end{array}$ & $\begin{array}{l}\text { Impact of use and } \\
\text { disposal of materials } \\
\text { on air and water } \\
\text { quality }\end{array}$ & $\begin{array}{l}\text { Disposal of sewage } \\
\text { and solid waste, en- } \\
\text { vironmental impact }\end{array}$ & $\begin{array}{l}\text { Sustainability of eco- } \\
\text { system services }\end{array}$ \\
\hline $\begin{array}{l}\text { Natural Hazards } \\
\text { and } \\
\text { Extreme Weather }\end{array}$ & $\begin{array}{l}\text { Decisions about } \\
\text { housing in areas } \\
\text { vulnerable to flood- } \\
\text { ing, tidal and wind } \\
\text { damage }\end{array}$ & $\begin{array}{l}\text { Rapid changes (e.g. } \\
\text { earthquakes), slow } \\
\text { changes (coastal } \\
\text { erosion), risks and } \\
\text { benefits }\end{array}$ & $\begin{array}{l}\text { Climate change, ex- } \\
\text { treme weather eve }\end{array}$ \\
\hline Land Use & $\begin{array}{l}\text { Conservation of ag- } \\
\text { ricultural lands and } \\
\text { natural areas }\end{array}$ & $\begin{array}{l}\text { Impact of develop- } \\
\text { ment and diversion } \\
\text { of water, water- } \\
\text { sheds, and flood } \\
\text { plains }\end{array}$ & $\begin{array}{l}\text { Production and loss } \\
\text { of topsoil, loss of ar- } \\
\text { able land }\end{array}$ \\
\hline
\end{tabular}

In line with the complex methodology of the PISA survey, the study authors then accompany us through several other important decisions that have to be made before the actual development of questions and tasks for assessing environmental literacy under the proposed framework. They describe the overall structure of the assessment questionnaires, propose the percentage representation of the contexts in the test tasks and the relative proportions of the tasks focusing on the different environmental literacy components, deal with the issue of suitable format of the test answers (the proportion of constructed response items and selected response items, etc.) so that the assessment is as faithful and equitable as possible while being feasible.

\section{Discussion}

The discussion below aims to focus on three main topics: summarising the strengths and potential weaknesses of the new definition of environmental literacy; the possibilities of utilising the new definition in the Czech context; and the current situation regarding the inclusion of environmental literacy in the PISA international assessment. 


\subsection{Strengths and weaknesses of the new definition of environ- mental literacy}

We regard its tight connection to the previous frameworks and, most importantly, research concerning environmental education and literacy, as the greatest strength of the new definition of environmental education in the NAAEE project. The summary description and organisation of the domain of environmental literacy shown in the single page of Diagram 1 is supported by a massive body of literature indeed (the bibliography contains approximately 250 items) reflected by the authors when developing the diagram. Each constituent component of environmental literacy that appears in the diagram is explained in detail and the authors justify its inclusion with existing research. The authors therefore not only present us with the result of their work - the overall diagram of the domain of environmental literacy - but also disclose the process by which they achieved the result, and justify their choice with research results. It appears to us that this procedure has not been customary in many of the previous frameworks defining environmental education, and that the amount of evidence gathered on which the authors have relied when composing the new definition is above standard.

Another strength, related to the first, is the composition of the team itself, of the authors and other experts who put the new definition together. The internal team unites people who bring their experience of making numerous previous frameworks defining environmental education (Marcinkowski), implementation of recent national environmental literacy surveys in the USA and Turkey (McBeth and Marcinkowski) and the concept of literacies in the PISA surveys (Zoido). Before finalisation, the work of the internal team was subjected to an extensive commenting process by other experts on environmental education, evaluation of results in education as well as related natural and social scientific disciplines. We are not aware of any other framework defining environmental literacy that has undergone such an intense and broad expert discussion in the development process.

Another possible strength is that the new description of the domain of environmental literacy is composed directly with regard to the needs of its assessment. The chapter presenting the new definition of environmental literacy is followed by a chapter in which the authors show how this definition can be applied in assessing environmental literacy in the PISA (Hollweg et al., 2011). It is the first time that the domain of environmental literacy has been described and organised similarly to the other literacies included in the PISA surveys. However, the proposal of environmental literacy assessment in the PISA can also be understood as an example of how the new description of the domain of environmental literacy can be utilised in creating other potential assessment tools.

It might seem that this last strength could also be a weakness. Is the regard to assessment in the new description and organisation of the environmental literacy domain too strong, and is it not too constricted? We do not think that it the case. The description of environmental literacy presented also includes dispositions, attitudes and competencies that are difficult to evaluate. Moreover, the authors of the new definition are very well aware of this pitfall. They have made a description of a truly broadly conceived environmental literacy domain. The decision about what in the domain to focus on when making specific tools for assessing environmental literacy is always with the creators of these assessment tools. The authors of the new definition of environmental literacy show us how they proceeded in making the proposal for assessing environmental literacy in the PISA. Obviously, they only selected some of the environmental literacy components for that: those that the PISA survey will be capable of assessing at least partly with respect to the time, organisational, technical and financial capacities that the PISA offers. While doing that, they try to proceed so that the selected environmental literacy components on which the assessment will focus still 
make a representative coverage of the entire environmental literacy domain as they have defined it. This work method when developing an assessment tool is highly transparent. We can see not only the components of environmental literacy on which the assessment will concentrate but also to what extent this concentration covers the entire domain of environmental literacy.

\subsection{Applicability of the new definition of environmental literacy in the Czech context}

The Czech Republic now has an attractive opportunity to make a detailed comparison between the NAAEE definition of the domain of environmental literacy and the Recommended Expected Outcomes of Environmental Education as a cross-curriculum topic and the Goals and Indicators of Environmental Education, Training and Awareness Raising. Both the documents, published by Czech Ministries in 2011, try to clearly define and organise the goals and sub-domains of environmental education and thus are de facto the first such frameworks for defining environmental education in the Czech context.

The Recommended Expected Outcomes of the Environmental Education as a crosscurriculum topic (Pastorová et al., 2011), which were drawn up under the jurisdiction of the Ministry of Education, Youth and Sports (more precisely, the Pedagogy Research Institute which is subordinate to the Ministry), define the goals and detailed expected outcomes of teaching environmental education at primary and secondary schools. The document defines 5 main areas of environmental education (to which it refers as key topics to establish a connection to the framework education schemes), namely sensitivity, principles, problems and issues, investigation skills, and action strategies. The document Goals and Indicators of Environmental Education, Training and Awareness Raising (Broukalová et al., 2011) was drawn up by a broader working group under the jurisdiction of the Ministry of the Environment. It defines goals of EE, including sub-goals and their explanations, and proposes possible indicators for assessing whether these goals are achieved successfully. The document describes the following areas of EE: relationship to nature, relationship to place, ecological processes and principles, environmental problems and issues, and readiness to act to the benefit of the environment. Although the two documents differ in their approach and contain partly different areas and sub-goals of environmental education, their basic concepts are in accord. At the same time, the two documents take inspiration from Anglo-Saxon frameworks for environmental education, even though they sometimes exceed those frameworks (for example, by including the issues of contact with nature and nature/culture interpretation in the latter document).

There are some great differences between the NAAEE definition of environmental literacy and the environmental education definition in both the Czech documents. While environmental literacy (recognised as the goal of environmental education in other publications) is the pivotal term in the NAAEE paper, this term is not found in either of the Czech documents (both define the goal of environmental education as development of competencies for responsible environmental behaviour). The organisation of the domain of environmental literacy in the NAAEE paper and the domain of environmental education in the Czech documents differs at first sight. The basic NAAEE environmental literacy classification includes dispositions, knowledge and competencies applied for the purpose of responsible environmental behaviour in certain contexts. The basic classification of environmental education in the Czech documents includes sub-domains such as relationship to nature, ecological processes and principles, environmental problems and issues, etc. On the other hand, it seems that the Czech documents share many ideological points of departure with the American one. It is clear, for example, that the Czech papers too take into account previous frameworks defining environmental education known on the international scale. However, detailed 
analysis comparing the Czech documents with the American one exceeds the purpose of this article.

The other major opportunity for using the new NAAEE definition in the Czech context offers itself in connection with environmental literacy assessments. The reason is that the term environmental (or ecological) literacy is found in the Czech context chiefly in surveys that verify the degree of environmental literacy shown by different groups of people. However, environmental literacy is defined differently in different surveys, and very different tools and questions are applied in its evaluation (see, e.g. Činčera and Štěpánek, 2007; Matějček and Bartoš, 2012; Dvořáčková and Ryplová, 2012). Some surveys make use, or partial use, of the New Environmental Paradigm (NEP) as a tool for measuring environmental attitudes. With respect to the trends abroad, some surveys strive to capture multiple areas such as various knowledge and skills, environmental attitudes and pro-environmental behaviour. The issue of appropriateness of adopting and translating assessment tools from abroad, which were developed in different cultural environmental education contexts, is also discussed (see, e.g. Franěk, 2012). One of the most recent surveys tries to develop a new evaluation tool that would conform to the Czech context and thus cover all the areas included in the Recommended Expected Outcomes of Environmental Education (Dvořáčková a Ryplová, 2012).

The new definition of the environmental literacy domain presented here is a very good tool for interpreting existing, and drawing up new, assessments to detect the level of environmental literacy among various groups (pupils, teachers, regional populations, etc.). It is remarkable how greatly the various environmental literacy assessments in the Czech Republic differ based on how the assessment authors understand the term - in turn determining what they measure - yet they all produce conclusions on the level of the groups' environmental literacy. The diagram of the domain of environmental literacy presented here may provide a framework of reference for assessing whether the Czech research conforms to the contemporary understanding of environmental literacy on the international scene. It may also help determine and describe precisely which environmental literacy components each assessment captures and which it neglects.

The NAAEE project presented may also be a rich source of inspiration for how to draw up similar documents defining the environmental education domain, or design evaluations verifying the success of our educational efforts. The authors map their points of departure and sources of inspiration, explain every component included in the new definition of environmental literacy, ground its inclusion in research results, reveal the questions that they asked themselves, and justify the decisions they made. The thoroughness, honesty and expert erudition in this procedure demonstrate the high standards that we should apply to ourselves when drawing up similar documents and assessments in the Czech Republic.

\subsection{Environmental literacy as part of the PISA}

Will the level of environmental literacy really be identified in the international PISA survey in 2015 based on the proposal presented here? It seems, sadly not. According to the information published by the OECD on the PISA survey at the time of writing this article, the 2015 survey will test science literacy, complemented with the area of collaborative problem solving (OECD, 2013b). Yet everything indicated for a long time that environmental literacy was the candidate. For example, the Pearson agency, which won the contract for developing the electronic tests for PISA 2015, presented its framework for environmental literacy alongside those for natural science literacy and team cooperation in handling problems in 2012 (De Jong, 2012). 
The non-inclusion of environmental literacy in the PISA is a thwarted opportunity for the growth of environmental education. It is certainly true that any measurement is burdened with error, and the PISA survey is no exception in this. As Jana Straková points out, this assessment as a comprehensive selective assessment is burdened with considerable selection and measurement errors (Straková, 2011). We have seen in the NAAEE proposal presented how the environmental literacy domain is narrowed down into several key components that may be partly verified in PISA. However, realising all these limitations, the data on the level of environmental literacy of the fifteen-year-olds obtained in PISA 2015 would have provided priceless feedback for further growth of environmental education. In most of the countries, it would have been the very first representative and comprehensive survey dealing with environmental literacy, moreover a survey conforming to the strictest methodological quality standards and producing internationally comparable results. It can be expected that the survey of environmental literacy under 2015 would initiate expert debate on its definition, evaluation and educational programmes aimed at developing it in many of the countries and on the international scale. The PISA has gained considerable renown and enjoys the attention of educational policy makers as well as the media and the general public. The inclusion of environmental literacy could therefore have contributed to a greater recognition of its importance both internationally and in the participating countries. It remains a question whether the non-inclusion of environmental literacy in PISA 2015 has thwarted this opportunity for good or whether we may see it fulfilled at some point in the future.

\section{Conclusion}

It will be interesting to see how much influence the new definition of the environmental literacy domain will gain despite the fact that environmental literacy has not become part of the PISA 2015. A unique set of experts was involved in developing and commenting on the definition, which made it possible to connect the findings and experience of development of previous environmental education frameworks, recent national environmental literacy assessments in several countries and literacy assessment under the PISA. The description of the environmental literacy domain that they have drawn up is unprecedentedly supported with research results and other literature. Therefore, the new definition is in many ways a representation of the best of the Anglo-Saxon traditional concept of environmental education as well as the modern concept of literacy and its assessment. We therefore recommend that everyone who deals with assessment of environmental literacy at various levels or will attempt a new definition of the domain of environmental education should become familiar with the NAAEE document.

\section{Bibliography:}

- Broukalová, L., Broukal, V., Činčera, J., Daniš, P., Kažmierski, T., Kulich, J., Lupač, M., Medek, M., Novák, M., (2011). Cíle a indikátory pro environmentální vzdělávání, výchovu a osvětu v České republice. Praha: Ministerstvo životního prostředí České republiky. Retrieved from http://www.mzp.cz/C1257458002F0DC7/cz/cile_indikatory_evvo_dokument/\$FILE/OEDN-Cile a indikatory EVVO-20110118.pdf

- Činčera, J. (2011). Doporučené očekávané výstupy pro environmentální výchovu. Envigogika, 6(2), 10-14712. Retrieved from http://www.envigogika.cuni.cz/index.php/Envigogika/article/view/59 http://dx.doi.org/10.14712/18023061.59 
- Činčera, J., \& Štěpánek, P. (2007). Výzkum ekologické gramotnosti studentů středních odborných škol. Envigogika, 2(1), 10-14712. Retrieved from http://www.envigogika.cuni.cz/index.php/Envigogika/article/view/12 http://dx.doi.org/10.14712/18023061.12

- De Jong, , \& J. H. A. L, (2012). Framework for PISA 2015. Presentation at 4th Annual Conference of Educational Research Center. March 24 -25 2012, Broumana, Lebanon. . Retrieved from http://www.educationalrc.org/conference2012/PDF/Prof\%20John\%20de\%20Jong.pdf

- Dunlap, R. E., \& Van_liere, K. D. (1978). The "New Environmental Paradigm. Journal of Environmental Education, 9, 4(4), 10-19. Retrieved from http://www.tandfonline.com/doi/abs/10.1080/00958964.1978.10801875 http://dx.doi.org/10.1080/00958964.1978.10801875

- Dvořáčková, S., \& Ryplova, R. (2012). Sonda environmentální gramotnosti studentů př́rodovědně a ekologicky zaměřených oborů na Pedagogické fakult. Envigogika, 7(3), 10-14712. http://dx.doi.org/10.14712/18023061.77

- Franěk, M. (2012). Nature Relatedness Scale. Český překlad škály měříí spojení s prírodou. Envigogika, 7(1), 10-14712. Retrieved from http://www.envigogika.cuni.cz/index.php/Envigogika/article/view/69 http://dx.doi.org/10.14712/18023061.69

- Hollweg, K. S., Taylor, J. R., Bybee, R. W., Marcinkowski, T. J., McBETH, W. C., \& Zoido, P. (2011). Developing a framework for assessing environmental literacy. Washington, DC: NAAEE. Retrieved from http://www.naaee.net/sites/default/files/framework/DevFramewkAssessEnvLitOnlineEd.pdf

- Hungerford, H. R., \& Volk, T. L. (1990). ., 21(3), 8-21. Retrieved from http://www.tandfonline.com/doi/abs/10.1080/00958964.1990.10753743 http://dx.doi.org/10.1080/00958964.1990.10753743

- Matějček, T., \& Bartoš, J. (2012). Environmentální gramotnost učitelů a studentů učitelství. Envigogika, 7(2), 10-14712. Retrieved from http://www.envigogika.cuni.cz/index.php/Envigogika/article/view/75 http://dx.doi.org/10.14712/18023061.75

- NAAEE. (2000). Environmental Education Materials: Guidelines for Excellence Workbook. Washington . Retrieved from http://resources.spaces3.com/83a622d9-c732-4c9a-8e31-aca1afa7a9b5.pdf

- NAAEE. (2004). Environmental Education Materials: Guidelines for Excellence. Washington. . . Retrieved from http://resources.spaces3.com/3725a5c0-f0ab-40399bd2-c5dbd9bcb34f.pdf

- NAAEE. (2009). Nonformal Environmental Education Programs: Guidelines for Excellence. Washington . Retrieved from http://resources.spaces3.com/b33925e669d6-4832-8442-5e3f32287b7b.pdf

- NAAEE. (2010a). Excellence in Environmental Education: Guidelines for Learning (Pre K-12). Washington . Retrieved from http://resources.spaces3.com/89c197bf-e630-42b0-ad9a-91f0bc55c72d.pdf 
- NAAEE. (2010b). Guidelines for the Preparation and Professinal Development of Environmental Educators. Washington . . Retrieved from http://resources.spaces3.com/e42d12db-f327-46ca-94c2-647060d23e74.pdf

- NAAEE. (2010c). Early Childhood Environmental Education Program: Guidelines for Excellence. Washington . Retrieved from http://resources.spaces3.com/91ecfc062076-4e26-880d-2332e87b5caf.pdf

- OECD (2005). The Definition and Selection of Key Competencies. Executive Summary . . Retrieved from http://www.oecd.org/pisa/35070367.pdf

- OECD. (2009). Green at 15? How 15-year-olds perform in environmental science and geoscience in PISA 2006. Paris. . .

- OECD. (2013a). About PISA. . Retrieved from http://www.oecd.org/pisa/aboutpisa/

- OECD. (2013b). PISA 2015 Draft Frameworks .. Retrieved from http://www.oecd.org/pisa/pisaproducts/pisa2015draftframeworks.htm

- PALEČKOVÁ J a kol, (2007). Hlavní zjištění výzkumu PISA 2006. Poradí si žáci s přírodními vědami?. : Ústav pro informace ve vzdělávání.

- Straková, J. (2011). Ke kritice výzkumu PISA. Orbis Scholae, 123-127. Retrieved from http://www.orbisscholae.cz/archiv/2011/2011 3 07.pdf

- ÚIV. (2006). Koncepce př́rodovědné gramotnosti ve výzkumu PISA 2006 . : Praha: Ústav pro informace ve vzdělávání.

- UNESCO (1975). The Belgrade Charter. A Global Framework for Environmental Education. Paris. Retrieved from http://unesdoc.unesco.org/images/0001/000177/017772eb.pdf

- UNESCO. (1978). Intergovernmental Conference on Environmantal Education, Tbilisi, 14 - 26 October 1977. Final Report. ED/MD/49. Paris . . Retrieved from http://unesdoc.unesco.org/images/0003/000327/032763eo.pdf 